\title{
Values-based Business Education for Empowerment, Self-Reliance and Poverty Reduction in Nigeria
}

\author{
Titus Amodu Umoru ${ }^{1, *}$ \\ ${ }^{1}$ Department of Business Education, Kwara State University, Malete, Nigeria \\ *Correspondence: Kwara State University, Malete, Nigeria. Tel: 234-803-351-9030. E-mail: umoruglo@yahoo.com
}

Received: June 18, 2013

Accepted: July 15, $2013 \quad$ Online Published: August 4, 2013

doi:10.5430/wje.v3n4p35

URL: http://dx.doi.org/10.5430/wje.v3n4p35

\begin{abstract}
This study centered on values-based business education for empowerment, self-reliance and poverty reduction in Nigeria. The study identified 30 critical values business education students need to possess. 192 questionnaire items were constructed after careful review of literature (Njoku, 2007 and Living Values Education, 2013) and administered them to 170 year I to 4 business education students, College of Education, and 22 lecturers of College of Education, Kwara State University, Malete, Nigeria. All the respondents completed and returned their questionnaire. One research question, "what are the values required by business education students for empowerment, self-reliance and poverty reduction in Nigeria?" was answered using mean and standard deviation. One hypothesis, "Lecturers and students do not differ significantly in their views regarding values required for empowerment, self-reliance and poverty reduction in Nigeria" was tested using t-test statistics. It was found that students need to possess these identified values in order to be empowered for self-reliance, and poverty reduction in Nigeria. It was recommended, among others, that all the identified values be learned along-side business education subjects so that business education graduates will not only imbibe these values but also exhibit those values in real life situations
\end{abstract}

Keywords: values-based business education; empowerment; self-reliance; poverty reduction

\section{Background of the Study}

In Nigeria today, it is very obvious that poverty is a constant factor. Poverty exists in multi-dimensional scales. This is because the economy is not growing as fast as expected. Graduates from universities, especially business education graduates are jobless. While few jobs are being created, business education graduates do not fit into such available few jobs due to the absence of needed values-based skills and. This situation seems to be getting worse as Nigeria daily witnesses disruption of economic and social life of the people by militants, kidnappers and religious fundamentalists.

Business Education as a discipline is structured through its course offerings to inculcate into the students traits of resourcefulness, endurance, and innovativeness. Furthermore, the challenges of embedding these identified values into the teaching process lies squarely within the purview of business education. Business education teacher may then ask: how do we accomplish the teaching of values or character education to our students? The answer is to apply teaching strategies that best meet the objective at hand using consensus building, cooperative learning, conflict resolution and service learning. At the same time, business educators should act as role models, practice respect continually in an interpersonal atmosphere and together with the University authority, ensure that the classroom climate is conducive, caring and civil. The argument, on the other hand, is not that values be taught to business education students separately rather it should be incorporated into the traditional business education subjects adopting the following approaches as suggested by Superka, Ahrens and Hedstrom (1996):

1. Inculcation (having students incorporate the standards and norms of his/her relevant group or society primarily through modeling, rewards, and sanctions)

2. Moral development (having students move through the stages of moral reasoning based on higher sets of values, using primarily discussions of moral dilemmas.)

3. Analysis (helping students use a rational, scientific investigation to decide issues of values and ethics, often using case studies.) 
4. Values clarification (helping students identify their own and others' values, often with role playing games or simulations as well as discussions and self-analysis.)

5. Action learning (using values classification or/and other approaches, providing students with opportunities to put values into practice with social action.)

If business education subjects are delivered using the above identified approaches and in the values-based atmosphere, the learners will be sufficiently stimulated through receiving information and internal reflection to be capable of exploring values in the real world. At the end, the students would be transformed having been equipped with personal, social and emotional skills and interpersonal communication skills which will enable them transfer what has been learnt into values-based behaviours in real life.

Value means to be worthy or highly priced; the quality of being useful or important. Njoku (2007) mentioned many of these values and states that for any group of people or society, their values are those things they consider as important in life. Living Values Education (2013), listed twelve values of great importance. These are: peace, respect, cooperation, freedom, happiness, humility, love, responsibility, simplicity, tolerance and unity. These values according to the document are needed for development of the individual and the world around him. It therefore implies that the development of the individual has a close link with that of the nation. Whatever action taken to inculcate these values in the mindset of business education students in order to influence their norms, interests and belief towards worthwhile goals is a right step in the right direction. Such worthwhile goals would affect their thoughts, actions, habits, characters and indeed their destiny as youth and help to take their minds away from restiveness and curb the social maladies aforementioned.

Narayan (2002) defined empowerment as the expansion of assets and capabilities of poor people to participate in, negotiate with, influence, control and hold accountable, institutions that affect their lives. Similarly, Wikiinvest (2013) described empowerment as an attitudinal, structural and cultural, process whereby people gain ability, authority, and agency to make decision and implement change in their own lives and the lives of other people. To be self-reliant is to rely on one's own capabilities, judgment, or resources; to be independent. Self-reliance is essential for job success, establishment and efficient management of personal business. These traits can be acquired by students when the identified values formed the bases of their character. Corruption has distorted the value system of Nigeria. According to the National Commission (2004) corruption and the abuse of positions and privileges have long been features of Nigeria's economic and political landscape. Systemic corruption and low levels of transparency and accountability have been major sources of development failure in Nigeria. Corruption not with-standing, a fast growing nation like Nigeria is expected to have youths that are likely to be poor as a result of age and dependency. This is made worse when those of school age cannot afford the cost of education. Similarly, the educated ones find no job due largely to the slow or non-growing economy with a high rate of inflation. Furthermore, since the Nigerian traditional system accepts the burden of childhood dependence, certain marriage practices, extended relationships, widowhood related problems and old age dependence, poverty vulnerability is expected to persist. is therefore, not surprising that Nigeria is passionately committed to partner with the United Nations in the realization of its Millennium Development Goals by 2015.These goals became the link-chain in Nigeria's on-going initiatives and processes under the New Partnership for African Development (NEPAD) and the National Economic Empowerment and Development Strategy (NEEDS).For the Millennium Goals to be achieved the youth must be empowered through tackling social exclusion and job generation to improve incomes, housing, healthcare, education and security. But these imperatives are not achievable without inculcating into the students these critical values.

\section{Problem of the Study}

Values affect attitudes and behaviour. It is for this reason that nations inculcate in youths the virtues of patriotism, discipline, honesty, integrity and selfless service since the youths are believed to be the leaders of tomorrow. But in Nigeria these important values seem to have been eroded. The Nigeria society is at the crossroads. A society that does not frown at wealth acquired by all means is in danger of extinction. Corruption is rife in Nigeria because values are placed on money over other desirable attributes such as these identified values. Misplaced values are the cause of rising crime wave (kidnapping, robbery and terrorism), fallen standard of education, unemployment and extreme poverty. According to the National Planning Commission (2004) in 1999 an estimated 99 per cent of Nigerians had income of less than $\$ 1$ a day while over 75 per cent of employable youths have no jobs, nor have things changed for the better. Therefore, the problem of this study is to reveal how values-based business education can empower students to be self-reliant and reduce poverty in Nigeria. 


\section{Research Question}

What are the values required by business education students for empowerment, self-reliance and poverty reduction in Nigeria?

\section{Research Hypothesis}

Lecturers and students do not differ significantly in their views regarding values required for empowerment, self-reliance and poverty reduction in Nigeria.

\section{Methodology}

Descriptive survey design was adopted since the study was concerned with collecting data from a population in order to explore their opinions (Best and Khan, 1992; Ali, 1996). The population of the study consisted of 192 respondents made up as follows: 170 year 1 to 4 students of business education, Kwara State University, Malete and all the 22 lecturers, College of Education of the same university. It is believed that students and lecturers of business education being members of the society should understand very clearly the identified values in the society. The entire population was studied without sampling because the population was manageable.

\section{Instrumentation}

The questionnaire was the instrument used. It was developed after a careful review of previous studies and discussions with colleagues who understand the Nigerian value system. The questionnaire was of a structured undisguised format. All items in the questionnaire were stated in a 5-point Likert format ranging from Strongly Agree $=5$, Agree $=4$, Undecided $=3$, Disagree $=2$ and Strongly Disagree $=1$.It was validated by colleagues from Kwara State University, Malete. The questionnaire contained a total of thirty items. A total of 192 copies of the questionnaire were administered with the help of two research assistants and all the questionnaire items were retrieved.

\section{Techniques for Date Analysis}

Data obtained were analyzed with the mean and standard deviation to answer the research question while the t-test statistics was employed to test the null hypothesis at 0.05 level of significance. A mean value of 3.50 and above indicated respondents' agreement with an item while a mean value of 3.49 and below indicated respondents' disagreement with an item. A calculated t-value that is equal or greater than the table value was considered significant and the null hypothesis rejected while a calculated t-value that is less than the table value was considered non-significant and the null hypothesis not rejected.

\section{Data Analysis and Results}

Table 1: Respondents' Views on Values Needed for Empowering the Youth for Sustainable Development

\begin{tabular}{llllllllll}
\hline S/no & Items & $\begin{array}{l}\text { Strongly } \\
\text { Agree }\end{array}$ & Agree & Undecided & Disagree & $\begin{array}{l}\text { Strongly } \\
\text { Disagree }\end{array}$ & Mean & $\sigma$ & Decision \\
\hline 1 & Handwork/industry & 128 & 42 & 22 & - & - & 4.5 & 0.7 & Agreed \\
2 & Honesty & 102 & 39 & 30 & 15 & 6 & 4.1 & 1.1 & Agreed \\
3 & Uprightness & 90 & 35 & 25 & 21 & 21 & 3.8 & 1.4 & Agreed \\
4 & Justice & 82 & 57 & 27 & 26 & - & 4.0 & 1.1 & Agreed \\
5 & Charity & 111 & 30 & 11 & 10 & - & 4.1 & 0.7 & Agreed \\
6 & Decent Dressing & 77 & 15 & 80 & 20 & - & 3.8 & 1.1 & Agreed \\
7 & Integrity & 141 & 30 & 11 & 10 & - & 4.6 & 0.8 & Agreed \\
8 & Patience & 121 & 61 & 10 & - & - & 4.6 & 0.6 & Agreed \\
9 & Tolerance & 53 & 63 & 60 & 6 & 10 & 3.7 & 1.1 & Agreed \\
10 & Accountability & 133 & 53 & 6 & - & - & 4.6 & 0.7 & Agreed \\
11 & Responsibility & 113 & 83 & 3 & 3 & 1 & 4.5 & 0.6 & Agreed \\
12 & Respect & 102 & 165 & 10 & 10 & 7 & 3.7 & 0.7 & Agreed \\
13 & Love & 192 & - & - & - & - & 5.0 & 0.0 & Agreed \\
\hline
\end{tabular}




\begin{tabular}{llllllllll}
\hline 14 & Appreciation & 66 & 100 & 20 & 6 & - & 4.2 & 0.7 & Agreed \\
15 & Cleanliness & 82 & 110 & - & - & - & 4.4 & 0.5 & Agreed \\
16 & Punctuality & 126 & 39 & 19 & 8 & - & 4.5 & 0.8 & Agreed \\
17 & Cooperation & 21 & 146 & 18 & 7 & - & 3.9 & 0.6 & Agreed \\
18 & Commitment & 139 & 33 & 11 & 7 & 2 & 4.6 & 0.8 & Agreed \\
19 & Reality & 130 & 31 & 11 & 11 & 9 & 4.4 & 1.1 & Agreed \\
20 & Humility & 109 & 76 & 7 & - & - & 4.5 & 0.6 & Agreed \\
21 & Self-discipline & 110 & 45 & 37 & - & - & 4.4 & 0.8 & Agreed \\
22 & Sexual Purity & 41 & 69 & 75 & 7 & - & 3.8 & 0.8 & Agreed \\
23 & Modesty & 69 & 100 & 23 & - & - & 4.2 & 0.6 & Agreed \\
24 & Compassion & 82 & 81 & 11 & 12 & 6 & 4.2 & 1.0 & Agreed \\
25 & Assistance & 144 & 48 & - & - & - & 4.8 & 0.4 & Agreed \\
26 & Peace & 78 & 72 & 30 & 12 & - & 4.1 & 0.9 & Agreed \\
27 & Freedom & 155 & 29 & 8 & - & - & 4.8 & 0.5 & Agreed \\
28 & Happiness & 192 & - & - & - & - & 5.0 & 0.0 & Agreed \\
29 & Simplicity & 141 & 21 & 28 & 2 & - & 4.6 & 0.8 & Agree \\
30 & Unity & 111 & 30 & 37 & 14 & - & 4.2 & 1.0 & Agree \\
\hline
\end{tabular}

Result in table 1 showed that all the items have mean values well over 3.50 which is our stipulated positive decision rule. Twenty-four items stand out with mean scores of well over 4.0. This is an indication that the society holds these values in high esteem. This view was supported by the finding of Njoku (2007) which placed these values at a premium level for any nation that hopes to survive. The standard deviation ranged between 0.0 and 1.4 which indicated low variability in the opinion of the respondents.

Table 2: T-test Result of Effects of Status (Lecturers and Students) on Their Views Regarding Values Needed for Student Empowerment, Self-reliance and Poverty Reduction in Nigeria

\begin{tabular}{lllllllll}
\hline Status & Number & $\sigma$ & Mean & $\begin{array}{l}\text { Degree of } \\
\text { Freedom }\end{array}$ & t-cal & t-crit. & $\begin{array}{l}\text { Level of } \\
\text { significance }\end{array}$ & decision \\
\hline Lecturers & 22 & .60 & 3.69 & & & & & \\
Students & 170 & .72 & 4.01 & 190 & 1.71 & 1.98 & 0.05 & Accept \\
\hline
\end{tabular}

Table 2 showed that the calculated $t$-value of 1.71 is less than the table value of 1.98. This indicated the acceptance of the null hypothesis of no significant difference between the mean opinions of lecturers and students regarding the values business education students needed to possess to be empowered for self-reliance and poverty reduction in Nigeria.

\section{Discussion}

The study was an attempt to ascertain very necessary values business education students needed to possess to be empowered for self-reliance and poverty reduction in Nigeria. The need for the students to imbibe the right values which will enable them to be gainfully engaged is clearly seen in the views of the respondents as all the values were accepted as critical by all the respondents. The striking similarity of opinions of lecturers and students is an indication of the acceptance of the values by the society. This is in conformity with NEEDS (2004) which anchors its policy on the restoration of those fundamental values for Nigeria to move forward. However, the reality is that the values exhibited by the students are at variance with those they claim to be worthy of possessing. While the respondents accepted decent dressing, sexual purity, and integrity, for examples, as critical values needed to be possessed, indecent dressing, sexual promiscuity and cultism are the order of the day in various campuses in Nigeria. Perhaps the parents are not alive to their responsibility of inculcating desirable values in their children. Another reason why the students seem not to portray accepted values may have to do with the fact that our universities are hardly values-based institutions. We have the curriculum, the teachers and facilities, albeit, all in half-measures. Teaching in our universities is neither inspirational nor student-centred. Business education cannot imbue planned learning experiences or scaffold students to imbibe desired values when schools are closed most part of the year due to strikes; when Muslim fundamentalists are bombing schools; when facilities are inadequate; and teachers ill-prepared. Yet, according to Tillman (2002), a student-centred learning requires environment in which relationships are based on trust, caring and respect naturally enhance motivation, creativity, and affective and cognitive development. Supporting the need for 
values-based schools and values-based curriculum, Lovat (2009) stated that students become more academically diligent, the school assumes a calmer, more peaceful ambience, better student-teacher relationship are forged, student and teacher wellbeing improves and parents are more engaged with the school. This makes it imperative for teachers of business education to aim at inculcating into the students values identified in this study. This is in line with the view of Oborah (2006) as he maintained that values are critical to the survival of the Nigerian nation and borders on the various national life, ranging from the individual, governments, institutions, and business organizations.

\section{Conclusion}

It is evident that the business education students need to possess the identified values from this study. The lecturers and students are unanimous in their opinion that these values are very important even though the values depicted by the students are at variance with the attitudes they portray. It is for this reason that unemployment is high, corruption is rife and poverty is severe justifying the need for values-based teaching and values-based schools so that graduates of business education would be empowered to be self-reliant, help in poverty reduction and sustainable development in Nigeria.

\section{Recommendations}

Based on the findings of this study the following recommendations are made:

1. All the identified values should be learned along-side business education subjects so that students will not only imbibe these values but also exhibit those values in real life situations.

2. The universities should be institutions exuding values-based atmosphere which draws students to higher level of moral development

3. A reward system needs to be put in place by the universities so as to encourage students to work hard, to be honest and display integrity at all times.

4. Universities should ensure that staff and students benefit from respectful and caring interactions in the teaching and learning process.

5. The Federal Government of Nigeria owes it as a duty to secure live and property so that the required values-based environment in our universities would be engendered.

\section{References}

Ali, A. (1996). Fundamentals of Research in Education. Awka: Meks Pub. Ltd.

Best, J.W., \& Kahn J.V. (1992). Research in Education. New Delhi: Prentice Hall.

Living Values Education: Values Education for children and young adults. Retrieved 25th Sept 2006 from http://living.values.net/resources/index.html

Lovat, T., Toomey, R., Dally, K., \& Clement, N. (2009). Project to test and measure the impact of values education on student effects and school ambience. Final report for the Australian Government Department of Education, Employment and Workplace Relations (DEEWR) by the University of Newcastle, Canberra: DEEWR.

Narayan, D. (2002). Empowerment and Poverty Reduction: A source Book. Washington DC: World Bank Publication. http://dx.doi.org/10.1596/0-8213-5166-4

National Economic Empowerment and Development Strategy (NEEDS) (2004). Abuja: National Planning Commission.

National Planning Commission. (2004). Federal Government of Nigeria. Abuja: Nigeria.

Njoku, C.U. (2007). Business Education and Value Orientation for National Economic Empowerment and Development. Business Education Journal, 4(1), 101-115.

Oborah, J.O. (2006). An Assessment of critical Business values for Business organizations in Nigeria. Business Education Journal, 4(1), 126-140.

Okoro, F. (2006). "Business Education and Value Orientation," Paper presented at the National Conference of the Association of Business Educators of Nigeria at Owo, Ondo State. 
Superka, D., Ahrens, C., \& Hedstrom, J. (1976). The values Education Sourcebook. Boulder, CO: Social Science Education Consortium.

Tillman, D. (2002). Living Values Activities for Young Adults. Deerfield, FL: HCI.

Www.Wikinvest.Com/Concept/Youth Empowerment, Visited May, 29, 2013. 